\title{
ВІД КАВКАЗУ ДО АБІССІНІЇ: ВАЖКИЙ ШЛЯХ БРИТАНСЬКОГО КОНСУЛА ЧАРЛЬЗА ДУНКАНА КЕМЕРОНА (1825-1870 рр.)
}

Анотація: Відтворено життєпис британського консула Чарльза Дункана Кемерона (18251870), який у 1858-1860 рр. був віще-консулом у кавказьких містечках Редут-Кале та Поті. Зазначено, що кавказька сторінка долі Ч. Кемерона не стала найяскравішою ні у його житті, ні в кар'єрі дипломата. Натомість сам він залишив яскравий слід в історії консульської служби Ї̈ Величності, пройшовши важкий шлях від бойового офіцера, учасника південноафриканських кампаній середини ХІХ ст. і Східної війни 1853-56 рр. до консула в Массауа (Абіссінія), де став вимушеним «учасником» ефіопської військової експедиції 1868 р. Остання не тільки перетворила консула Ч. Кемерона на героя, а й підірвала здоров's, що й поставило останню крапку у його наповненому подій життєвому шляху.

Ключові слова: дипломатія, консульство, Великобританія, зовнішня політика, консул, Кемерон, Південна Африка, Сухум, Редут-Кале, Поті, Кавказ, Абіссінія, Ефіопія

Історія консульств і дипломатичної служби зарубіжних країн набуває все більшої популярності серед українських дослідників. Даний напрямок для вітчизняної історичної науки є абсолютно новим і знаходиться на початковій стадії своєї дослідницької історії. Саме тому нами започатковано низку статей, які розкривають місце та роль британських консулів у соціально-економічному та політичному житті чорноморських портових міст Західного Кавказу. Дослідницьким завданням автор ставить відтворення життєпису одного $з$ консулів Великобританії, який у 1858-1860 рр. був віце-консулом у кавказьких містечках Редут-Кале та Поті, Чарльза Кемерона.

Дана стаття є продовженням попередньої роботи автора (саме з цієї причини ми не подаємо передісторію питання та історіографічну довідку з означеної проблеми), яка була присвячена першому британському консулу у Сухум-Кале Чарльзу Діксону․․ Як вже зазначалося у вказаній роботі, помічником Ч. Діксона у званні віце-консула був призначений Чарльз Дункан Кемерон (Charles Duncan Cameron, 1825-1870)², капітан, член Королів-

\footnotetext{
• Тригуб Олександр Петрович - доктор історичних наук, професор, завідувач кафедри міжнародних відносин та зовнішньої політики Чорноморського національного університету імені Петра Могили (м. Миколаїв); ORCID: https://orcid.org/0000-0003-0610-1702; e-mail: alextrigub@ukr.net

${ }^{1}$ Тригуб 0. Чарльз Ханмер Діксон - перший британський консул у Сухум-Кале (1858-1865рр.) // Старожитності Лукомор'я. 2020. №1 (1). С. 115-126. DOI: https://doi.org/10.33782/2708-4116.2020.1.15

${ }^{2}$ За винятком уточнень, біографічний нарис складено за наступними джерелами: Cameron Charles Duncan // Stephen L. (Ed.). Dictionary of National Biography. Vol. VIII: Burton-Cantwell. N-Y.: Macmillan and Co, 1885. P. 288; Herslet, Edward (Compiler). The Foreign Office List, Forming a Complete British Diplomatic and Consular Handbook. July 1870. London: Harrison, 1870. P. 69; Cameron Charles Duncan // Shinn, David H., Ofcansky, Thomas P. Historical Dictionary of Ethiopia. Lanham, Maryland: Scarecrow Press, 2013. P. 91-92; Cameron Charles Duncan. URL: https://alchetron.com/Charles-Duncan-Cameron
} 
ського географічного товариства (листопад 1858). Народився у Дугласі на острові Мен (Великобританія) 12 грудня 1825 р. у родині майора (пізніше підполковника - Lieutenant colonel) Алана Кемерона ${ }^{3}$ (Allan Cameron, 1777-1845) ${ }^{4}$ та Алети Борчердс (Aletta Jacoba Borcherds, 1787-1865).

Спочатку Чарльз Кемерон обрав кар'єру військового і, придбавши офіцерський патент на звання прапорщика (молодшого лейтенанта) ${ }^{5}, 19$ травня 1846 р. він вступає на службу до 45-го Ноттінгемширського піхотного полку, який дислокувався на батьківщині матері (Кейптаун, Південна Африка), де прослужив до липня 1851 р. У 1854 р. його служба у резервістській частині полку була відзначена медаллю за участь у Сьомій Кафрській війні 1846-47 рр. ${ }^{6}$ (рис. 1).

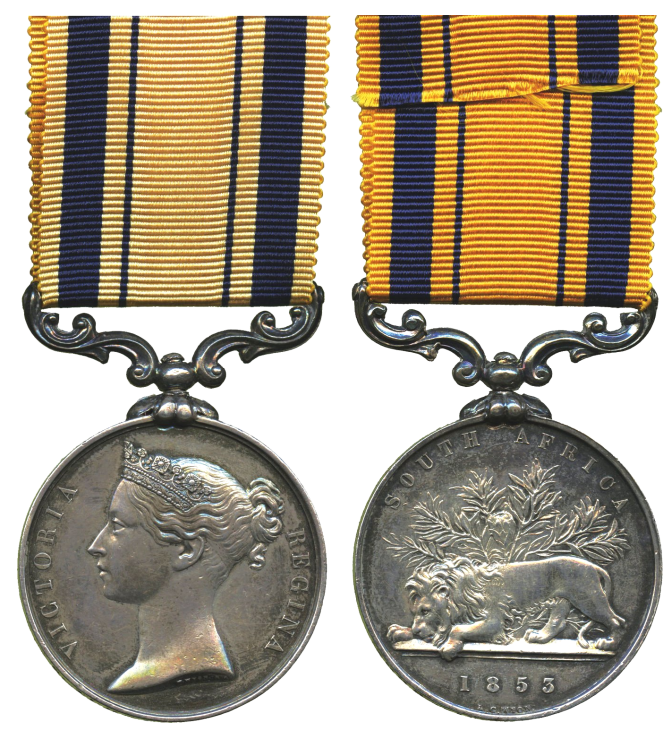

Рис. 1. Південноафриканська медаль британської армії (1854 р.) (срібло, Великобританія)
У 1851 р. Ч. Кемерон вийшов на пенсію й оселився у південноафриканській колонії Наталь, якою на той час управляв лейтенантгубернатор Бенджамін Пайн ${ }^{7}$. Останній запропонував Кемерону дипломатичну службу в країні Зулу (окремі дослідники вважають це початком його дипломатичної кар'єри) та виконання обов'язків адміністратора кафрського магістрату у районі річки Кліп (колонія Наталь). Окрім цього, за дорученням Б. Пайна, його було призначено командиром резервістів (1851-52), які були направлені на допомогу регулярній армії до Колонії Кейп під час Восьмої Кафрської кампанії 1850-1853 рр. Таким чином кар'єра молодого Ч. Кемерона розпочалася у Південній Африці, де він виконував різні адміністративні, політичні та військові доручення.

3 початком Кримської кампанії Ч. Кемерон повертається до армії, де був на-

\footnotetext{
${ }^{3}$ «Національний біографічний словник» (див. вище) помилково вказує полковника Чарльза Кемерона батьком Ч.Д. Кемерона, але згідно із метричним записом церкви Святого Георгія у Дубліні (https://www.familysearch.org/ark:/61903/1:1:XZYY-HD6) уточнено батьків і дату народження Ч. Кемерона. Вказаний запис свідчить, що вказівка на полковника Чарльза Кемерона є помилкою.

${ }^{4}$ А. Кемерон пішов до армії добровольцем у 1796 р. Служив в Індії та Південній Африці (де й помер). Див. URL: http://www.ancestryresearchservice.com/genealogy/getperson.php?personID=I5529\&tree=DonaldStrontian.

${ }^{5}$ Ф. Енгельс у своїй праці «Англійська армія» зазначив, що подібний патент коштував 450 фунтів стерл., що було досить солідною сумою того часу (Энгельс Ф. Английская армия // К. Маркс и Ф. Энгельс. Сочинения. Т. 15. Москва: Госиздат политической литературы, 1959. С. 627-644. С. 633).

${ }^{6}$ Кафрські «прикордонні» війни - війни колоніалістів Кейпської колонії Великобританії XVIII-XIX ст. 3 південноафриканським народом ко́са, яких європейці називали кафрами.

${ }^{7}$ Бенджамін Чіллі Кемпбелл Пайн (1809-1891) був у різні часи адміністратором Наталу, Золотого узбережжя, Антигуа, Островів Лівордс (British Leeward Islands) і Західної Австралії.
} 
правлений у фортецю Карс до підрозділу під командуванням Вільяма Фенвіка Вільямса ${ }^{8}$ отриманням капітанського звання турецької армії (27 березня 1855 р.). Навесні 1855 р. призначений начальником фортифікаційних укріплень Ерзерума. Після падіння Карса (листопад 1855 р.) був відряджений на спеціальну службу до Тробзона, де пробув до вересня 1856 р. За вірну службу під час російсько-турецької війни отримав дві турецьких медалі: «За оборону Карса» та «Кримську медаль» (рис. 2).

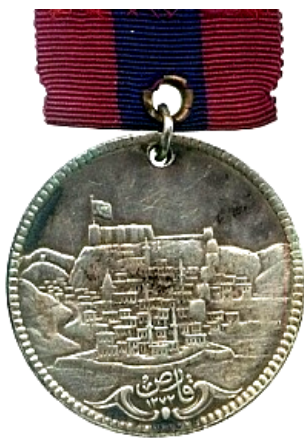

Рис. 2.1. Медаль «За оборону Карса» (срібло, Османська імперія, 1855)
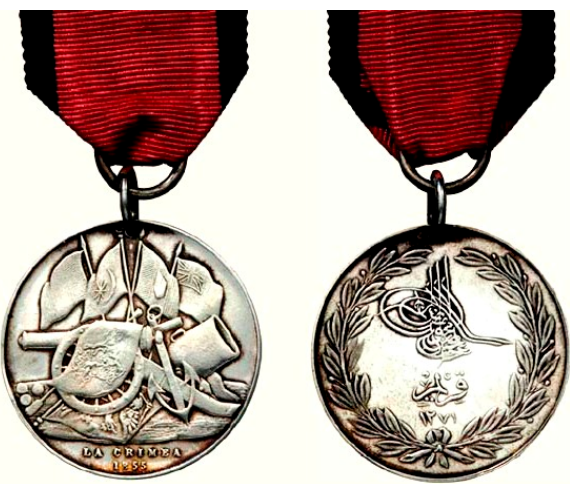

Рис. 2.2. Кримська медаль (срібло, Османська імперія, 1856)

По завершенні війни Ч. Кемерон залишає військову службу та вирішує перейти на державну службу. Для цього у 1858 р. він успішно складає спеціальний іспит перед Комісією 3 державної служби й 16 червня 1858 р. отримує відповідний сертифікат (Honorary Certificate). Ще до отримання сертифікату 20 квітня 1858 р. він отримує дипломатичне призначення на посаду віце-консула у Редут-Кале ${ }^{9}$, тобто помічником сухумського консула Ч. Діксона. Через рік, 23 квітня 1859 р. його переміщають до Поті, що було пов'язано 3 необхідністю більш ефективної організації консульської роботи у регіоні, оскільки з відкриттям влітку 1858 р. царським урядом потійського порту для іноземних торгівельних суден $^{10}$ та облаштування зручної дороги Сухум-Тифліс, редуткальський портовий рейд втратив своє торгівельне значення.

Коло питань, якими опікувався на Кавказі віце-консул у Редут-Кале та Поті, були подібними до сфери діяльності консула Ч. Діксона. У Foreign Office збереглося три спра-

\footnotetext{
${ }^{8}$ Вільљм Фенвік Вільямс, 1-й баронет Карський (Sir William Fenwick Williams, 1800-1883) - британський генерал, учасник Кримської війни, губернатор Нової Шотландії (Канада) та Гібралтару. Під час Східної війни формально перейшов на турецьку службу з чином феріка (генерал-майора) і під час облоги Карса російськими військами командував обороною фортеці.

${ }_{9}^{9}$ Редут-Кале - місто-фортеця для захисту Мінгрелії від турків, заснований росіянами на узбережжі Чорного моря у 1804 р. в сімнадцяти верстах на північ від Поті у гирлі річки Хопі. Спочатку Редут-Кале іменувався фортецею, з 1840 р. - місто, 1846 р. - портове місто. Редут-Кале служив перевалочним пунктом для товарів, що йшли із Середземного, Чорного й Азовського морів на Закавказзя. Саме тут європейські кораблі вивантажували свої вантажі (шлюпочним методом у відкритому морі), які потім переправлялися до Тифлісу по суші, зазвичай на в'ючних тваринах (у 1851-60 pр. у середньому щорічно відпускалося на 388 тисяч руб., привозилося на 288 тис. руб. товарів). 3 облаштуванням сухумського і потійського портів, втратив торгівельне значення, оскільки не мав зручної пристані для безпосереднього завантаження/розвантаження кораблів.

${ }^{10}$ The London Gazette. 1858. June 15. P. 2922.
} 
ви $^{11}$, які містять листи Ч. Кемерона до Лондона та звіти про ситуацію у підпорядкованому районі. Для дослідників історії Кавказу кінця $50-\mathrm{x}$ - початку 60 -х років XIX ст. особливий інтерес представляє справа, що містить рапорти Ч. Кемерона по Кавказу у двох частинах, де подається на лише опис подій, а й презентовано політичні, економічні, статистичні, військові, демографічні й інші характеристики регіону ${ }^{12}$.

Пробув на Кавказі Ч. Кемерон недовго і

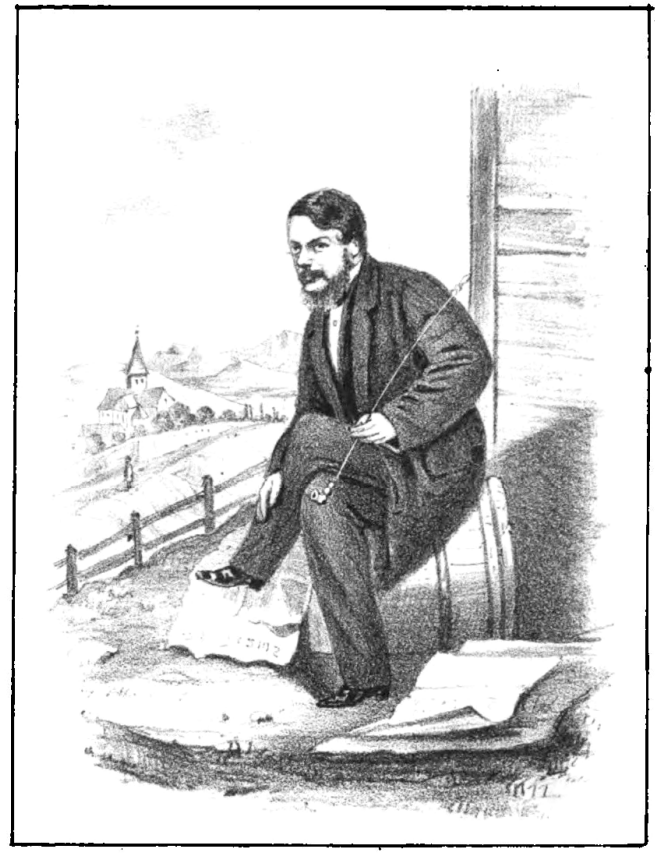

CONSUL C. D. CAMERON

Рис. 3. Консул Ч.Д. Кемерон (книжна гравюра 1860-х років) $)^{13}$ 30 червня 1860 р. його було направлено консулом до Абіссінії (Ефіопія) з резиденцією у місті Maccaya (Massowah) ${ }^{14}$. До місця призначення консул прибув лише 9 січня 1862 p., відбувши у дорогу в листопаді 1861 р. з Лондона, де він отримав чіткі вказівки від міністра закордонних справ Дж. Рассела: отримати максимум політичної інформації про ситуацію в Абіссінії, але не втручатися у внутрішні справи (це було пов'язано з тим, що попередник Кемерона - консул Волтер Плоуден, зблизившись 3 абіссінським царем, імператором Теодором II, 13 березня 1860 р. був убитий одним із політичних опонентів царя) $)^{15}$.

Для ознайомлення 3 консульським округом і кращого розуміння місцевих особливостей у 1862 р. він взяв участь у відомій експедиції герцога Саксен-Кобург-Готського Ернеста II по Абіссінії.

У червні 1862 р. Ч. Кемерон вирішив налагодити відносини 3 королем і 23 червня прибув до столиці міста Гондер (ймовірно, переїзд до нової столиці - Магдали, ще не відбувся). Королю він подарував зброю (пістолети та гвинтівки), а також вітальний лист від імені королеви Вікторії. Тоді ж, не дивлячись на наявність вказівки «не втручатися» у політичні справи, як писав у своєму звіті Кемерон, він обговорював новий англо-абіссінський договір з королем та можливий обмін дипломатичними представництвами. У листі король запропонував свій проект договору, який мав антиосманський характер; просив дозволу направити дипломатичне представництво до Великобританії та покровительства його підданим для вільного проходу через єгипетську територію, обмеживши проникнення Єгипту на узбережжя ${ }^{11}$ F0 65/525 «Consuls Dickson, Cameron, Lorentz» (1858); FO 65/563 «Consuls Dickson, Cameron, Lloyd» (1860); F0 65/569 «Captain Cameron's Report on the Caucasus» (1860).

${ }^{12}$ FO 65/569 «Captain Cameron's Report on the Caucasus» (1860).

${ }^{13}$ Margoliouth M. Abyssinia: Its Past, Present, and Probable Future. A Lecture, with Notes and Appendices. London: Published by Request, 1866. (ч/б вставка на початку книги).

${ }^{14}$ The London Gazette. 1860. July 24. P. 2719; The Edinburgh Gazette. 1860. July 27. P. 949.

${ }^{15}$ Hooker J.R. The Foreign Office and The 'Abyssinian Captives' // Journal of African History. 1961. Vol. II (2). P. 245258. P. 245-246. 
єгипетську територію, обмеживши проникнення Єгипту на узбережжя Червоного моря; висловив бажання купляти вогнепальну зброю та будувати дороги ${ }^{16}$. Передавши його консулу, просив повернутися якнайшвидше з відповіддю. Останній відправив його разом зі звітом лише у кінці 1862 р., який дійшов до Лондона лише у лютому 1863 p. Foreign Office був незадоволений політичними ініціативами Кемерона та наказував йому не проявляти самоуправства та повернутися до Массауа ${ }^{17}$. Але це вже був не початок історії....

у 1860 р. до Ефіопії прибув англійський місіонер Генрі Аарон Стерн (Henry Aaron Stern, 1820-1885), який повинен був проповідувати християнство серед ефіопських євреїв. Теодор II прихильно поставився до місіонерів, що дало їм можливість центр місії розмістити у столиці Гондер. Після того як король не отримав від Кемерона королівської відповіді на свою пропозицію, він розцінив це як неповагу до своєї королівської персони, і його ставлення до британців почало змінюватися на охолоджено недружнє. У результаті, у жовтні 1863 р. Г. Стерна було викликано до імператора і його, разом з декількома місіонерами, ув'язнили у гондерській тюрмі й у 1864 р., у зв'язку з перенесенням столиці, переведено до Магдали.

Вогню до незадоволення короля Стерном, як стверджувала англійська преса, додало те, що Теодор II, який вважав себе божим посланником і нащадком легендарного царя Соломона, був ознайомлений з книгою місіонера «Мандри серед фалашів в Абіссінії: разом з описом країни та її різних мешканців» («Wanderings among the Falashas in Abyssinia: together with a description of the Country and its various Inhabitants», 1862), де той зазначив про просте (селянське) походження Теодора II (у Foreign Office вважали, що король мав доступ навіть до англійської преси $\left.{ }^{18}\right)$.

У листопаді 1863 р. Ч. Кемерон, особисто прибувши на аудієнцію до короля, висловив протест проти ув'язнення британських підданих і вимагав звільнити Г. Стерна й інших бранців, а також просив почекати з відповіддю королеви на лист Теодора. Натомість консул і його неофіційний помічник 3 січня 1864 р. (деякі джерела стверджують, що Кемерон був ув'язнений вже в грудні $1863 \mathrm{p.}^{19}$ ) самі опинилися у полоні з обвинуваченням «за втручання у внутрішню політику королівства» ${ }^{20}$. Гнів короля проти консула був посилений і тим, що останній так і не привіз британської відповіді на свій лист до королеви Вікторії (дослідник Дж. Хукер стверджує, що листа, не прочитавши, помилково відправили до відділу, який опікувався справами Індії (India Office) і таким чином лист тинявся по MЗС до того моменту, поки про нього не згадали у зв'язку з ув'язненням британців ${ }^{21}$. Кемерон був змушений написати Лондону лаконічне повідомлення: «Не звільняйте, поки не надійде цивільна відповідь на королівський лист» ${ }^{22}$.

\footnotetext{
${ }^{16}$ Cameron Charles Duncan // Shinn, David H., Ofcansky, Thomas P. Historical Dictionary of Ethiopia... P. 92.

${ }^{17}$ Hooker J.R. Op. cit. P. 246-247.

${ }^{18}$ Hooker J.R. Op. cit. P. 250.

${ }^{19}$ Beke Charles T. The British Captives in Abyssinia. London: Longmans, Green, Reader, and Dyer, 1867. P. 2.

${ }^{20}$ Cameron Charles Duncan // Stephen L. (Ed.). Dictionary of National Biography... P. 288.

${ }^{21}$ Hooker J.R. Op. cit. P. 247-248.

${ }^{22}$ Rubenson, Sven. The Survival of Ethiopian Independence. London: Heinemann \& Esselte Stadium, Addis Ababa University Press, 1976. IX+436 p. P. 237.
} 
31 жовтня 1865 р. «Лондонська газета» висловила власне бачення причин конфлікту Теодора II і консула Кемерона:

«Головною причиною гніву імператора на консула Кемерона була його подорож до [племені] богосів, поєднана з підозрою імператора, що консул Кемерон інтригував налаштувати проти нього турків та єгиптян прикордоння та, певною мірою, загострився поверненням консула Кемерона до Гондара без жодної відповіді на лист імператора до королеви» $»^{24}$.

Ч. Кемерон залишався в'язнем Теодора II до приходу Ормуза Рассама ${ }^{25}$ у табір імператора в січні 1865 р. О. Рассам мав копію запізнілої відповіді на лист імператора, яка повинна була забезпечити звільнення всіх європейських полонених Теодора II. Ув'язнених відпустили, але після показового судового розгляду Ч. Кемерон, місіонери та навіть їх рятувальник О. Рассам були 12 липня 1866 р. заарештовані знову й ув'язнені у Магдалі.

У жовтні 1866 р. лорд Стенлі ${ }^{26}$ попросив

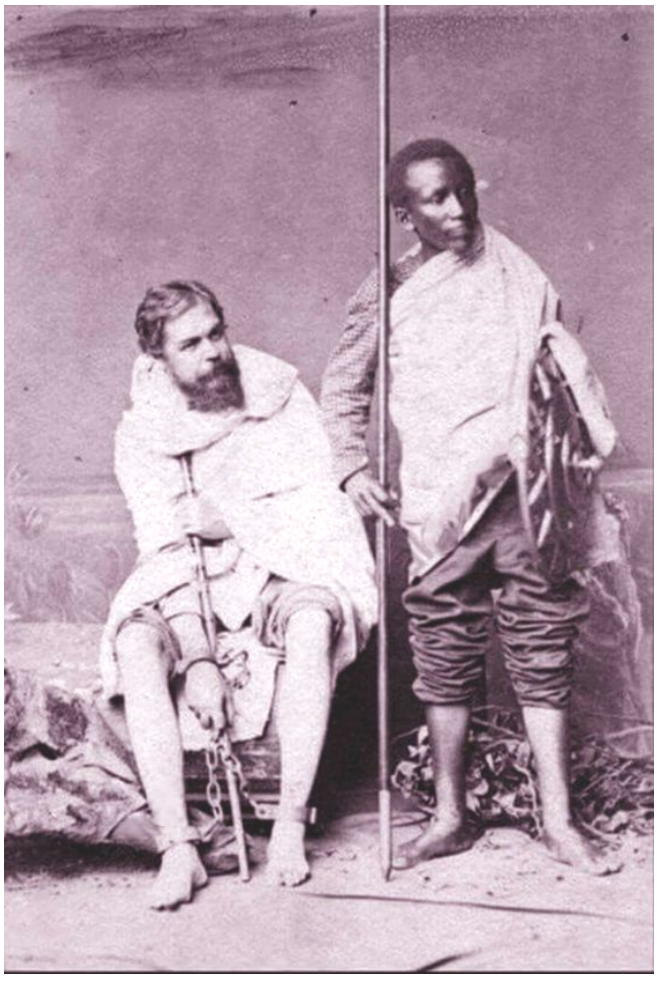

Рис. 4. Ч.Д. Кемерон в ув'язненні (середина 1860-х рр.) $)^{23}$ Військове міністерство (War Office) розглянути можливість військової експедиції. Натомість, до квітня 1867 р. жодних активних дій не проводилося, оскільки голова МЗС розраховував на те, що Теодор II, оточений повстанцями, міг бути повалений і бранці, як наслідок, звільнені. Але подіьного не сталося і 16 квітня 1867 р. Стенлі направив абіссінському імператору ультиматум, попередивши, що в разі незвільнення бранців протягом трьох місяців після відправки листа, дружелюбні відносини між ним і королевою припиняться.

Оскільки відповідь не надійшла, 19 серпня було прийнято рішення направити на взяття Магдали підрозділ із Бомбея (Індія) на чолі з Робертом Нейпіром. Згідно з офіційною англійською історіографією, офіційною метою військової експедиції було домогтися звільнення Кемерона й усіх інших офіційних осіб, що були затримані Теодором, а також будь-яких інших європейців. При цьому імператор не повинен був позбавитися якої-

\footnotetext{
${ }^{23}$ Cameron Charles Duncan // Генеалогічний проект GENi. URL: https://photos.geni.com/p13/90/8a/02/9b/534448413b01093d/charles_duncan_cameron_in_chains_11_original.jpg ${ }^{24}$ The London Gazette. 1865. October 31. P. 5086.

${ }^{25}$ Ормуз Рассам (англ. Hormuzd Rassam, 1826-1910) - османський іракський ассиріолог і мандрівник, який працював на британців. У 1866 р. британський уряд відправив його в експедицію до Ефіопії, де він був ув'язнений на два роки.

${ }^{26}$ Едуард Генрі Стенлі, 15-й граф Дербі (Edward Henry Stanley, 15th Earl of Derby, 1826-1893) - британський державний діяч. Міністр закордонних справ Великобританії.
} 
небудь частини своєї території чи піти на якісь поступки, як у грошовому еквіваленті, так і в інших. У разі захоплення Теодора, його потрібно було відправити до Бомбею 27.

Військова експедиція 1868 р. була короткою й успішною для британської армії: 12/13 квітня Магдала була захоплена та знищена, імператор покінчив із собою, бранці (рис. 5) були звільнені ${ }^{28}$.

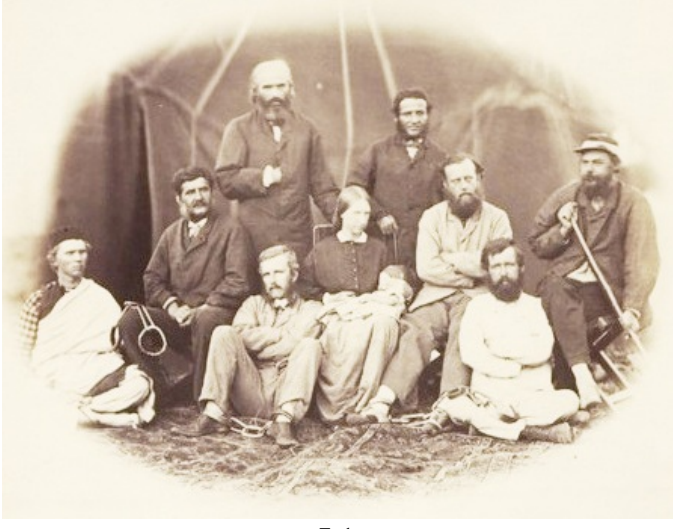

5.1.

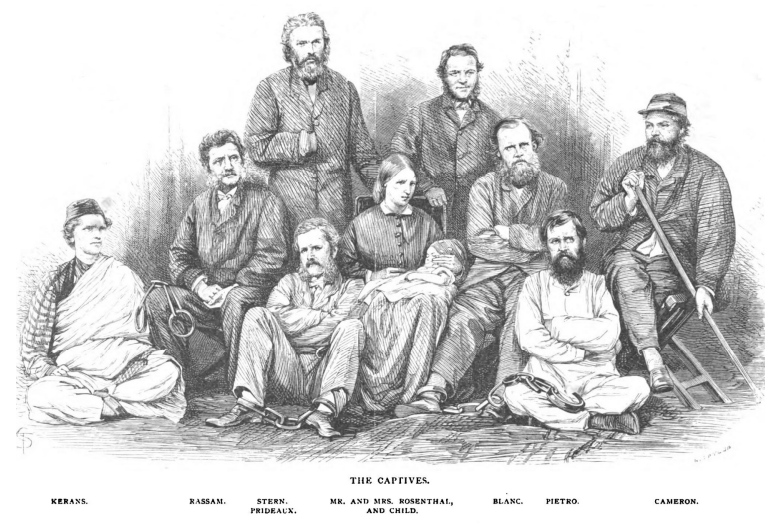

5.2.

Рис. 5. Бранці імператора Теодора II після звільнення (крайній справа - консул Ч.Д. Кемерон) 5.1. - оригінальне фото з альбому «Ефіопія» (Національний архів Великобританії, СО 1069/5/116)

5.2. - гравюра з фото, що використана у книзі Г. Стерна «Захоплені місіонери» ${ }^{29}$

25 липня 1868 р. Чарльз Дункан Кемерон повернувся до Англії та 7 грудня того ж року вийшов на пенсію. Ймовірніше за все, африканські пригоди далися взнаки його здоров’ю, оскільки він у 1869 р. виїхав на лікування до Швейцарії, де й помер 30 травня 1870 р. у Женеві ${ }^{30}$.

Ми бачимо, що кавказька сторінка долі Ч. Кемерона не стала найяскравішою ні в його житті, ні в кар'єрі дипломата. Натомість сам він залишив яскравий слід в історії консульської служби Ї̈̈ Величності, пройшовши важкий шлях від бойового офіцера, учасника південноафриканських кампаній середини XIX ст. і Східної війни 1853-56 рр. до консула в Массауа (Абіссінія), де став вимушеним «учасником» і героєм ефіопської військової експедиції 1868 р.

\footnotetext{
${ }^{27}$ Роберт Корнеліс Нейпір (Robert Cornelis Napier, 1810-1890) - британський військовий і державний діяч, фельдмаршал, губернатор Індії та Гібралтару, 1-й барон Нейпір Магдальский.

${ }^{28}$ Ward, Adolphus William, Gooch, George Peabody (Eds.). The Cambridge History of British Foreign Policy. Vol. 3: 1866-1919. New-York: Cambridge University Press, 2012. P. 17-19.

${ }^{29}$ Stern, Henry A. The Captive Missionary: Being an Account of the Country and People of Abyssinia. Emberacing a Narrative of King Theodore's Life, and His Treatment of Political and Religious Missions. London: Cassel, Petter and Galpin, Ludgate Hill, [1868]. 400 р. (ч/б вставка на початку книги).

${ }^{30}$ Cameron Charles Duncan // Shinn, David H., Ofcansky, Thomas P. Historical Dictionary of Ethiopia... P. 92.
} 


\title{
Oleksandr Trygub
}

\section{From the Caucasus to Abyssinia: the Difficult Road of the British Consul Charles Dun- can Cameron (1825-1870)}

\begin{abstract}
The biography of the British consul Charles Cameron, who in 1858-1860 was vice-consul in the Caucasian towns of Redout Kale and Poti, is reproduced.

Charles Duncan Cameron (1825-1870), captain, elected fellow of the Royal Geographical Society. He was born in Douglas on the Isle of Man (UK) in the family of a British Army major.

In 1846 he enlisted in the infantry regiment stationed in Cape Town (South Africa), where he served until July 1851.

In 1851-53 he began performing various diplomatic, administrative, political and military assignments in the Zulu country. During 1853-56 he took part in the Eastern (Crimean) War and received a several of Turkish awards.

In 1858 he began his diplomatic career as vice-consul in Redout Kale (Western Caucasus). In 1859-60 he was vice-consul in Poti. The main task of vice-consul Charles Cameron in the Caucasus was to inform the British government in detail about the political, economic, statistical, military, demographic and other characteristics of the region.
\end{abstract}

In 1860-68 he was consul in Massowah (Abyssinia / Ethiopia). In 1863 (1864) he was captured by the Abyssinian Emperor Tewodros, where he remained until his release in 1868.

On July 25, 1868, Charles Duncan Cameron returned to England and retired on a pension in December 7 of the same year. In 1869 he went to Switzerland for treatment, where he died in Geneva on May 30, 1870.

The Caucasian page of Cameron's fate did not become the brightest in his life or career as a diplomat. Instead, he himself left a bright mark in the history of Her Majesty's consular service.

Keywords: diplomacy, consulate, Great Britain, foreign policy, consul, Cameron, South Africa, Soukhoum, Redout Kale, Poti, Caucasus, Abyssinia, Ethiopia 